Sign Systems Studies 30.2, 2002

\title{
The abstract structure of the aesthetic sign
}

\author{
Elize Bisanz \\ Department of Applied Culture Studies, University of Lüneburg \\ Scharnhorststr. 1, Campus, Geb. 5, 21332 Lüneburg, Germany \\ e-mail: ebisanz@gmx.de
}

\begin{abstract}
Walter Benjamin foreshadowed many of the aesthetic theories, currently playing a fundamental role in the production and interpretation of art. By emphasising the role of the expressive character of art, or rather the category of expressivity itself, Benjamin defined art as a language. His aesthetics was characterised by the continuous interaction of two almost reciprocal projects: the theoretical critique of art which is based on an understanding of historical processes, and the understanding of historical processes which is formed by the critical experience of art. We find a fundamental similarity between Benjamin's dialectical character of the aesthetic sign and Lotman's double-sidedness of the artwork. In classifying the system of art as a language, both theoreticians space out the structure of art and determine it as the intersection of the synchronic and the diachronic aesthetic discourse. The paper follows the traces of the transition of modern painting from its representational status to an autonomous signification, that is, from being a symbolic expression to a discourse in the grammatological meaning of écriture. Parallel to this transition which resulted into the process of abstraction in painting, there can be observed a shift in the cultural values of art which had its critical bearing upon the world secured not by connections of likeness, but by virtue of the very independence of its values. The abstract form of the modern painting has been the declaration of the language of art as an exemplary realm. What must be expressed and experienced within this realm was (1) the critical reflection on the human condition, and (2) representing the society in so far as art maintained a moral independence from those conditions. This dialectic between the autonomous and social character of art has left deep impacts on the language of painting, a complexity, which has been made transparent through the various semiotic analytic approaches of the aesthetic sign. The paper discusses the processual character of the modern painting and demonstrates briefly the deficiency in the structural analysis of the painting language, encouraging its synthesis with the dynamical character of cultural products as we find it in the Lotmanian culture theory.
\end{abstract}


All kinds of human intellectual expressions could be understood as a sort of language, a point of view that opens a wide scale of new approaches. We can speak of a language of music and sculpture, of a language of law, that has nothing to do with the languages in which the German or the English law is written, of a language of technology that is not primarily the language of the technician. (Benjamin 1974 [1916]: 140)

In this sense, we can understand not only the Russian, French, Hindi etc. as languages, not only the artificial constructed systems within the different scientific forms that are used for the description of certain groups of manifestations, but also traditions, rituals, trading forms or religious thoughts. In the same sense we can talk about a "language" of theatre, film, painting, as well as about art in general, as a language that is organised in a specific way. (Lotman 1972: 20)

\section{The form in absentia}

Painting is one of the many forms of cultural expressions. It presents a special expressive form which invokes simultaneously our intellectual and emotional dispositions, the conscious and the unconscious at a time. On the one hand insists modern painting, as an image, on being comprehended and on the other hand it rejects every form of immediate manifestation and determination. The various methods of discussing abstraction in art demonstrate that the modern art, in its abstract form, puts a challenge of the systematic analysis of the work of art. In order to analyse the specific aesthetic character of abstract painting and to infiltrate the complexity of the art object, art-history or art-theory needs analytical modi that offer a certain flexibility, allowing to adjust themselves to the demands of the given art work.

The most common questions of the methodological perspectives of the traditional art-history belong to questioning categories like: what is painting? or, What does the work of art represent? Approaches that operate with such questions show a fundamental deficiency analysing the abstraction of the image-expression, for they lead inevitably to the reduction of the abstract form to a void corpus, existing in an artificial vacuum, disconnected from its signification system. Moreover, the reduction of the abstract work to a mere representational level fails to catch the very idea of the modernity in its structure which is: the 
rejection of art being defined through a representational and a communicative role of the painting-art within an artificial sign-system.

One of the unprecedented achievements of the modern abstract painting was its linguistic turn, that is, its defining painting as a language and doing so demonstrating its own textuality.

Thus an adequate approach to abstraction can be considered on a metalinguistic level which allows the reflection on the discursiveness, the boundaries and the topology of painting as art, encouraging questions like: on which level does painting begin? when can we determine it as art? or, how does it show itself as an abstract art? Parallel to questions concerning the defining features of the language of the painting expression, art-theory has to consider also the social dimension of the aesthetic expression. Artworks are both autonomous entities and forms of social expression; consequently, the reflection about abstraction in art can not be seen disconnected from the abstract state and the impacts of abstraction on the social life.

The parallels in time and place between the mass industrialisation and the outbreak of the classical modern art show that the process of cultural abstraction found its authentic form in works of art whose interpretation consequently leads to the interpretation of the cultural status in the industrialisation age. The impact of the modern condition was being primarily felt in Europe, having Paris as the pre-eminent centre of the avant-garde such as the cubism. None the less an avantgarde in the painting art developed also in the German-speaking world in centres such as Berlin, Dresden and Vienna, where a characteristic inflection towards the expressive and subjective could be observed. A third avant-garde impact is to be found in those urban centres which came as a later phase of modernisation in Italy and Russia, representing the distinctive rhythms of the modern status.

The response to the modern condition was experienced in two opposed directions. On the one hand, as a deep pessimism at the increasing control of human life by the machine, a sense of loss of freedom; on the other hand an almost hysterical exhilaration towards the mechanical achievements, speed and machinery. However different they may have been, the responses of depression and exhilaration were actually responses to the effects of modernisation having the common denominator the cause of the modern world. This became with the beginning of the First World War a dominant motif of art, understanding modernisation not only as a technological fact but also as a social fact, marked by the production of new social relations. 
Art understood itself on the one hand as the servant of an emancipatory social movement and on the other hand as an hermetic art like the cubism, making the picture and its language to a thing for itself. Cubism established itself as a paradigm for subsequent avantgarde art, with its unprecedented technical innovation performing modernity as the structure of the artistic work itself. The shift in technical priorities of the art work expresses a fixing upon the materiality and a specific form of opacity of the medium through which the world is represented.

Once this emphasis upon the means of representation was achieved, remaining unchanged in a permanent changing world, art secured its archaic role. On the one hand it understood itself as a sphere that decodes the modern world and even participate in changing it. On the other hand undergoing itself through a fundamental transformation. This problem of the relation of an autonomous art to wider social change has remained constitutive of the art in the modern period.

\section{Painting as language}

A very general and fundamental determination of painting is its being an expressive form that falls under the general category of visual language. The modern abstract painting is not only a product of the visual and pictorial language, it is also the reflection on it. Semiotically speaking: abstract painting as a sign is its signifié and signifiant at a time.

Within the aesthetical semiotics-tradition, such as in the Lotmanian sign-theories, the aspect of the double-sidedness has been declared to one of the essential conditions of the aestheticity. As the various semiotic surveys show, the moment of the double-sidedness proves to be very productive for the analysis of the abstraction. It is very important for the aesthetic sign that its form and content reciprocally represent each other. As Lotman (1972: 28) writes: the expression level is not only an essential factor of the sense, it is the construction scheme of the meaning.

Artworks can be defined as signs through the synthesis of all their components. The aesthetic sign can function as a vehicle of meaning through the whole structure of the aesthetic text. As Lotman emphasises, the particularity of the meaning of the aesthetic sign resides in its resistance against being translated through other sign systems. The 
meaning of the modern work of art has to be sought within the work itself, in the poeticity of the work.

Through the analysis of the painting as a language we approach the product of that language with its own means: painting explains itself through its own language.

Nevertheless, the language character of the painting does not contribute to an easier structural analysis; on the contrary, it unfolds a new dimension of complexity, for there exist various modes and theories of what we situate under the category of language. The problem is, that the different definitions of the language do not represent a homogenous discipline. The philosophical definition of the expressive language or the representation, determines the work of art through its semantical and representational aspects, whereas the syntactical categories are rather classified as secondary. The semiotic definition, on the other side, analyses the syntactical aspects of the paintings with the intention of reaching to a semantical explanation of the work. The methods of definitions vary between a synchronical or a diachronical strategy, that is, between the analysis of the form and the analysis of the content.

During the last twenty years there has been an encouraging development of the semiotics of the pictorial language; the different methods had developed themselves in different directions. This discrepancy results to a certain extent from the different definitions of the concept of languages and from the lack of distinction between the language of the spoken word - understood as a language with a closed sign-system, a vocabulary inventory and a grammatical system, characteristics which are inconsistent with the aesthetic character of art works - and the pictorial or visual language. Even semiotics, especially in its structuralist tradition, that has always insisted on the importance of the syntactical rules of a given text, could not develop adequate methods of the analysis of the aesthetic language of paintings.

\section{The language of pictorial art}

Painting as a language system is constructed by different ordinance than those of the word-language. For the interpretation of the art of painting we need a multiperspective analytic approach that considers the art-historical, the perceptual, the sociological, the physiological 
and the aesthetical point of views. Exactly through its multidisciplinary character is semiotics, in its semiological and culturological tradition, predestined for the explanation and interpretation of such complex phenomena. The productivity of semiotics of pictorial language does not lie primarily in the results of the semiotic investigations but rather in the unfolding of the analytical parcours, in the process of its methodological discourse.

The following example intends to verify this concept. For the analysis of the abstract painting semiotics offers a particularly interesting motive which is the concept of semiosis. As we know, semiosis is an event in which a thing will be transformed to a sign. It consists of three factors: $A$ an interpretation, $B$ an object or a quality of a relation or a state and $C$ the meaning that $A$ gives $B$. $A$ interprets $B$ as the representation of $C$. The different definitions of this relation and of the term sign build in their turn different semiotic methods. The logical semiotic tradition of Carnap and Morris defines $B$ as the sign, the linguistic tradition of Saussure and Hjelmslev defines the relation between $B$ and $C$ as the sign, whereas the Berlin semiotic school defines $A$ as the interpretant, $B$ as the sign and $C$ as the meaning. Despite of the fact that semiotics considers all this positions as complementary parts of the signification system, the concept of semiosis has not been represented as the entireness of the sign, but as a process in which signs are produced. Considering this concept and the development of the abstract painting we could say, that abstract painting could be defined in so far as a sign, if the concept of semiosis presents the totality of $A, B$ and $C$. A theoretical point of view which we find explicitly discussed in the Lotmanian culturology, especially in his definition of the aesthetic sign.

The dominance of the category of the form in the concept of abstract works facilitates its interpretation as a language and as a sign. Abstraction is the manifestation of such dimensions that can primarily be read by our perception. The structure of the language of painting manifests itself on this very physical and material level. It has to be stressed that, as the various movements of the modern art like the cubism, the surrealism, the informell, the conceptualism and others prove, it was the achievement of the modern art itself and not the theory of art, to emancipate its language from its instrumentalisation and converting it to a fundamental part of the art conception and the theoretical reflection.

Furthermore, the phenomenon of abstraction has shown a direct correspondence with the technical and scientific development and its 
impacts on the perception. Abstract images do not necessarily mean the transition of the image to pictorial things which are either empty signifiers or denotations of vague images. Abstract figures build images that, in presenting modes of comprehending abstract phenomena, train our perception to see and read abstract structures on a more general level. Also the theories of the optic and the psychology of perception explain the development of the perception from a mere receptive to a perceptive status, in which the perceiving subject reads images not only as representations but also as ways of conceiving complex structures.

Like every complex cultural phenomenon, it is difficult to determine the exact period of the outbreak of abstraction. For the concept of semiotic approach to the language of abstraction it is more important to follow the traces of its impacts on the language of the work than determining its beginnings. Impressionism is known to be the turning point for the art of painting, regarding its achievement in freeing the image from its mere representational position as a means of communication. The traces of the acceleration of the cultural development was also evident within the space of art; the permanent changes in styles and theories made it difficult to distinguish between the different positions in the field of art-production of the modern world. Another dimension of abstraction could be observed on a metalevel caused by speed of the cultural and social development. The constant changes in the field of art lead to a constant defragmentation of the form of its language, a phenomenon which paradoxically contributed to the manifestation of its language-form. Abstraction proved itself to be the impulse of the manifestation of the formlanguage of the art of painting.

One of the important components of this development was the concept of the spectator and its new position in the formation rules of the art-work. The modern artist made the perception to one of the constitutive moments of the work structure, as we can see in the works of surrealism. All these theoretical positions played an important role in the construction of a grammar of the language of painting.

The concept of a grammar of the language of painting does not necessarily oppose to the concept of the aestheticity of the art work, as long as grammar is not understood as a predefined and closed system of rules and categories for the production of aesthetic works. The goal of a grammar-concept of visual semiotics is not to display a series of changes of aesthetic elements, but to compose a grammar of the visual language, that can support the understanding and analysing the system 
of images. Hence, for the comprehension of abstraction, it is very important to distinguish between the tradition of a historical grammar - such as in the tradition of Alois Riegel - and the semiotic grammar concept, just like the Lotmanian distinction between the language of art and the traditional form-concept. Whereas the intention of the historical art-grammar was primarily the documentation of the changes of the artistic pictorial elements for a better understanding of the historical changes, a strategy that had neglected the important role for the reception and understanding of the works, focuses the semiotic grammar concept its attention explicitly on the categories of perception and production of works of art, such as styles, image-field etc.

In the semiotic tradition developed by Fernande Saint-Martin, in the mid $80 \mathrm{~s}$, a genuine semiotic grammar of the visual language has been formulated, continuing the interrupted tradition of Max Raphael. One of the important achievements of Saint-Martin's grammar concept proved to be her combining art-historical components with biological, physical and semiological categories. Saint-Martin declares the category of dynamics to the central characteristic of the visual and pictorial language, with the full awareness of its restrictive moment, that it is impossible to determine the limits and the final categories of this language, a difficulty such as we see with the example of defining the colour itself. The search for fixed categories replaces Saint-Martin instead with the search for energy-centres, a terminology that she has taken from the domain of physics. Saint-Martin (1987) calls the smallest element of such an energetic centre the coloreme.

A coloreme represents a constant energy which has the same dynamic origin as our ability of visualising things. Hence, the grammar of the visual language is the sum of the perceptive elements and the modes of combining the variables of the coloremes. It has to be mentioned that other than the word-language-system, the individual structure of the elements of the visual language differ from the structure of the visual language as a whole, which means that even if we can distinguish between the structures of different coloremes, we cannot guarantee an exact identical reproduction of the different coloremes.

The idea of a grammar of the artistic expression built also a relevant part of the Lotmanian art theory. Lotman understood the language of the art-work as a certain given volume or quantity of elements that preexist each individual work of art and which is equivalent for the both poles of the act of communication. Semiotics 
substituted the idea of perception of the traditional form-aesthetic with the concept of sign. Painting was then defined as a sign-system, that among other qualities was also understood as the documentation of the perceptive act. The reading and apprehending of the images was subsequently considered as directly attached to the social decodingabilities. The semiotic tradition criticised the notion of experience through art, arguing that experience as an individual activity, could not consider the social moment of the art-work, whereas the concept of sign could achieve this through its communicative moment.

The semiotic concept of the sign-character of the art-work, as we find it in the Lotmanian semiotics of culture, thinks the art-work as a discursive work that arises from the middle of the society. The artist uses the social codes and produces through them new sign-combinations, that on their part preserve the dynamics of the innovative energy without which the very existence of culture could be endangered. This shows that the definition of the art work as a sign fulfils the very idea of the dialectic work, which was considered by the aesthetics of the critical theory of Benjamin and Adorno as the central idea of the modern abstract art.

\section{Models of semiotic analysis}

Within the science of semiotics, we find different approaches to the phenomenon of abstraction of the image. The various methods have opened new dimensions for the science of art concerning the interpretation of abstraction. The art-works which had been analysed by those methods vary from classical modern to monochrom painting. The different semiotic methods, known as the structural analysis, the work-inherent analysis, the generative analysis and the topological analysis show, that the semiotics of the visual language can unfold its analytical properties not necessarily through producing new theories about the visual language but through its critical reflection about the forms of discourse about art.

However, the semiotic approaches do not simplify the task of analysing the works of art. On the contrary, every direct work-analysis follows its own definition of the concept of sign and sign-systems which has to be considered in the conception of the sign-study.

One of the important researches in the field of the visual language of art has been done by the Greimasian school. In their efforts to prove 
a certain universality of the Greimasian linguistic theories, Jean-Marie Floch and his colleagues analyse some abstract modern paintings, such as the works of Wassily Kandinsky. They not only take the pains to transpass all the different levels of several works of Kandinsky, but also add to it a diachronical analysis of Kandinsky's oeuvre and compose a formula illustrating the semiotic discourse of Kandinsky's entire work (Fig. 1).

expression

syntagmes

chromatiques

linéaires type 1 type 2

type 1 type 2 contenu

énoncés

: /combat/ : /jouissance du bonheur/

Figure 1. Kandinsky scheme.

The Greimasian semiotic scheme of Kandinsky's work divides the painting field in two levels: the expression level and the content level. On the expression level we see two syntagmas of the chromatic and linear levels that are marked as type 1 and type 2, translating the representations of war and happiness. On a second step it discusses the dichotomy of the chromatic level with the equivalents non-expression lexpression and the linear level with the equivalents dryness/nondryness which on their turn represent the meaning war and happiness.

The following application of the Greimasian method on two paintings from Gerhard Richter, a German contemporary painter, intends to illustrate the deficiencies of the analytical method. Nevertheless, the splitting of expression and the content levels into further sub-contents and sub-expressions contribute to the manifestation of the complexity of the painting-language. From this analytic strategy the abstract painting unfolds its different layers of meaning production.

One of the important achievement of the work of Gerhard Richter is its dialectical reflection on the language of painting and representation. With the category of visuality, of the visual expression and reception painting imposes its autonomous realm composed of figuration/abstraction, neutrality/expression. The wide scale of Richter's paintings since the sixties presents not only a strong evidence of the power and possibilities of the art of painting after the so called 
death of the art of painting, but also the important role of the image discourse especially in the era of its digitalisation.

The picture "Seestück (See-See)" from the year 1970 (Fig. 2) and "Stadtbild Paris" from the year 1968 (Fig. 3) represent two completely different concepts of aesthetic positions. Whereas the painting "Seestück (See-See)" belongs to a series of Richters works which can be understood as an interpretation of the romanticism, the picture "Stadtbild Paris" connotes the very idea of urbanism and the technological development. A semiotic analysis of the pictures reveals its critical discourse between the language of its representation and the romantic idea of representational painting, as well as the peculiarity of the syntactical dimension of the presentation form.

Further reflections on the semiotic structure and the comparison of the meaning construction of the two pictures coded in their different layers lead to further levels of the rhetorical statements. The shift in the styles and motifs from realistic to impressionistic, from the natural scenery of the sea to the cultural scenery of the metropolis, opens a space of a new textuality. The photographic precision of the romantic scenery comments the representational role of painting, whereas the impressionistic manner of the urban scenery stresses the central idea of the modernity in art. Further considerations of the photographic work of Richter show further dichotomies in style and meaning. We can see for example the category of colour in the photographic representations connoting an opposition to the absence of colour in oilpaintings.

This shows that, in order to reach the complex levels of meaning production we have to transcend the deconstruction of the language structure and proceed with a reflection on the conditions as well as on the parole of the language of painting, its mode expression. The methodological construction of the different positions, such as in the Greimasian model, remains reduced, despite its very rich terminology, either on the meta-level of the language system or on the text-level of the analysed work.

A complete understanding of the language of the art-work can only be achieved, if both levels of the analysis are combined to a general analysis of the work of art. This remaining a substantial precondition to distinguish the particularity and the aestheticity of different worksigns. The analysis methods of visual semiotics still show a certain deficiency in this topic. 



Figure 2. Gerhard Richter, 'Seestück (See-See)', oil-painting, 200x200 cm, 1970 (Staatliche Museen zu Berlin, Nationalgalerie). 

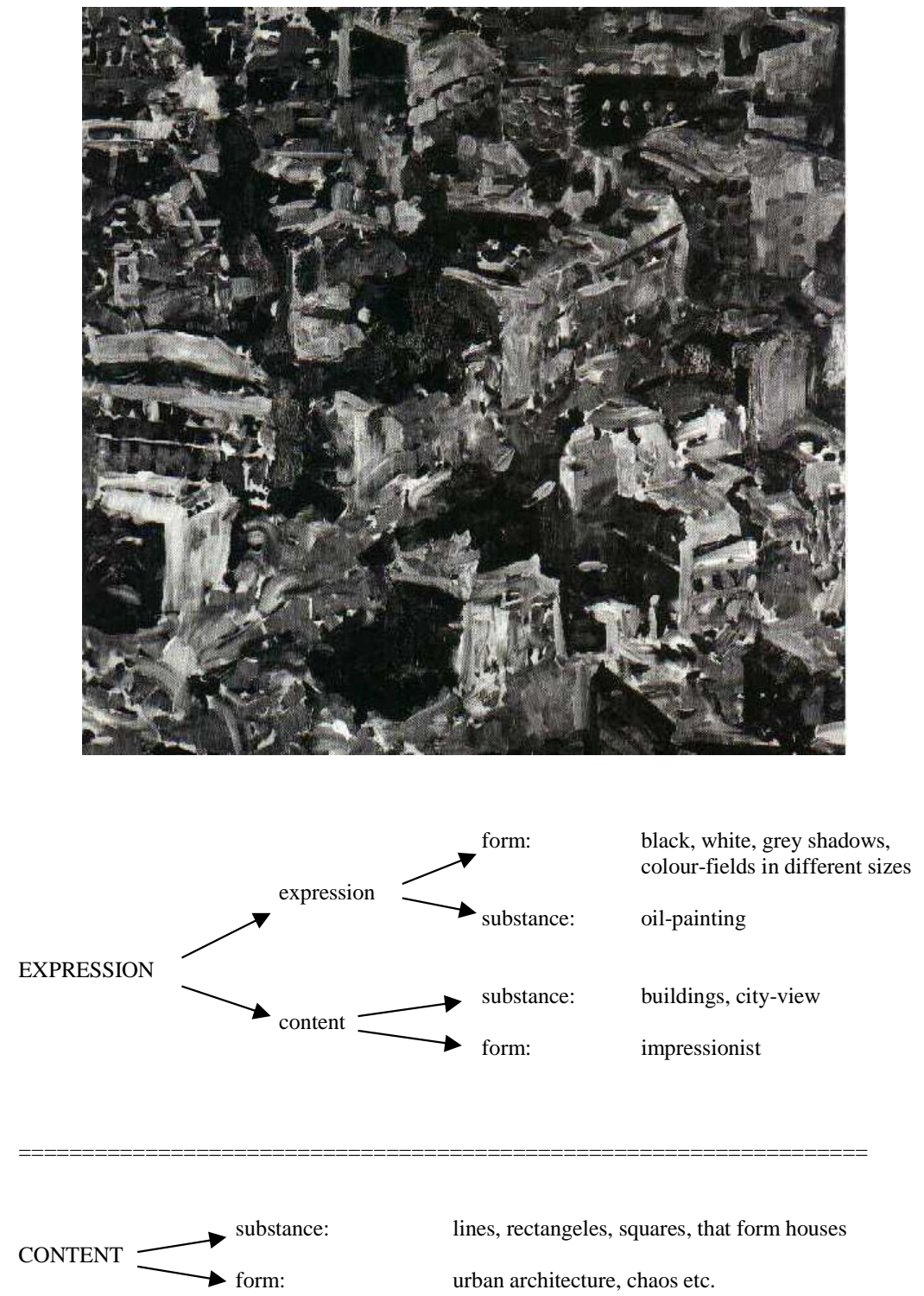

Figure 3. Gerhard Richter, 'Stadtbild Paris', oil-painting, 1968, 200x200 cm. 
A short comparison of the various image-semiotic methods with the Lotmanian positions shows not only the actuality of the Lotmanian culturological work, but also proves his wider horizon in exploring the work of art. The system-analytical method examines the system in which signs occur, the text-analytical method examines the sign and describes the system accordingly. The Greimasian concept of meaning differentiates between the natural meaning which is produced with the sign and the artificial meaning which is preformed meaning, whereas Lotman talks about an artistic system which produces always new meanings with the production of the sign itself, like the aesthetic sign and artificial sign which in his definition includes all the sign systems.

Through all his works Lotman insisted on the polyglottic character of culture, defining culture as the sum of different expressive forms or languages, not only within a given culture, but also as a transcultural form of expression. The elements of the cultural system understood Lotman in a constant interaction with each other, forming and reforming the cultural texture and producing its dynamical condition. With his concept of the text extends Lotman the semiotic boundaries beyond all of the mentioned methods. The text in its Lotmanian definition becomes a space of endless possibilities on and in which the human being experiences himself.

Also his contribution to a methodology of exploring the aesthetic sign Lotman has gone beyond the mentioned methods conceptualising the visual language of the art-work. He saw at least two levels of the work-interpretation, the definition of the elements of each sign-system and the definition of the relation of those elements to each other, which were of coarse meant as the starting point for the endless task of interpretation. Just as a work of art presents itself as the dialectical relation between the form and the content, between the techné and the idea declares Lotman aestheticity to the essence of every cultural production, to its dialectical moment of coding and decoding itself and sees the importance of the semiotic reflection in decoding those moments.

Hence, in its attempt to build a general theory of signs semiotics must avoid to neutralise the specificity of the different languageforms, of each cultural product and cultural form and of each aesthetic sign. More than a science of general sign-theory, semiotics can use all its theoretical facilities and utilities to develop itself to a science of forms in their diversity.

Exploring the condition of the aesthetic sign means exploring the boundaries of culture itself. The very idea of the aesthetic production 
has its cradle on the boundaries of our cultural identity: it is at the same time the definition and the extension of the cultural identity in its determination of the boundaries. In the age of the hypertexts and cyberworlds and their total dematerialisation more than ever, we need ways of outlining the features and the images of our abstract cultural state.

\section{References}

Adorno, Theodor W. 1973. Ästhetische Theorie. Frankfurt am Main: Suhrkamp. Barthes, Roland 1973. Le plaisir du texte. Paris: du Seuil.

- 1979. Elemente der Semiologie. Frankfurt am Main: Syndikat

Belting, Hans 1995. Das Ende der Kunstgeschichte. München: C. H. Beck Verlag.

Benjamin, Walter 1974 [1916]. Über Sprache überhaupt und über der Sprache des

Menschen. In: Benjamin, Walter, Gesammelte Schriften 2. Frankfurt am Main: Suhrkamp, 139-156.

Cassirer, Ernst 1923-1929. Philosophie der symbolischen Formen. Berlin: Cassirer.

Derrida, Jacques 1992. Die Wahrheit in der Malerei. Wien: Passagen.

Floch, Jean-Louis 1985. Petites mythologies de l'oeuil et de l'esprit: pour une sémiotique plastique. Paris: Editions Hadès-Benjamins.

Gombrich, Ernst H.1960. Art and Illusion. New York: Pantheon.

Greimas, Algirdas J. 1966. Strukturale Semantik: Methodologische Untersuchungen. Paris: Larousse.

- 1970. Du sens: essais sémiotiques. Paris: Editions du seuil.

Hjelmslev, Louis 1971. Essais Linguistiques. Paris: Minuit.

Kandinsky, Wassily 1952 [1912]. Über das Geistige in der Kunst. Bern: Benteli Verlag.

Lotman, Juri 1972. Die Struktur literarischer Texte. München: Fink.

- 1981. Kunst als Sprache: Untersuchungen zum Zeichencharakter von Literatur und Kunst. Leipzig: Reclam.

Panofsky, Erwin 1955. Meaning in the Visual Arts. New York: Doubleday.

Saint-Martin, Fernande 1987. Semiotics of Visual Language. Bloomington: Indiana University Press.

Thürlemann, Felix 1982. Paul Klee: Analyse sémiotique de trois peintures. Lausanne: L'age d'homme.

- 1990. Vom Bild zum Raum: Beiträge zu einer semiotischen Kunstwissenschaft. Köln: DuMont.

Worringer, Wilhelm 1996. Abstraktion und Einfühlung. Dresden: Verlag der Kunst. 


\section{Абстрактная структура эстетического знака}

Немецкий философ Вальтер Беньямин заложил основы нескольких более поздних эстетических теорий. Подчеркивая экспрессивный характер искусства, Беньямин определял искусство как язык. Для его эстетики характерно взаимодействие двух противоположных направлений: с одной стороны - художественная критика, опирающаяся на понимание исторических процессов, с другой - понимание критического опыта искусства в качестве оформителя исторических процессов. В этом проявляется фундаментальная близость в теориях эстетического знака у Беньямина и художественного произведения у Лотмана. Оба теоретика определяют искусство как язык и пересечение синхронического и диахронического эстетического дискурса в его структуре. В статье рассматривается изменение функции современного художественного произведения из репрезентативной в автономно сигнификативную, или из статуса символического выражения - в дискурс (в смысле грамматологического écriture). Параллельно с этим изменением имел место и сдвиг в культурном значении искусства. Критическое отношение искусства к миру обеспечивалось не подобием, а независимостью ценностей. Современная живопись декларирует язык искусства как сферу, позволяюшую, с одной стороны, критическое отображение человека, а с другой, репрезентацию общества, в той мере, в какой искусство является морально независимым от этих условий. Диалектика автономной и социальной природы искусства глубоко повлияла на язык изобразительного искусства, на что указывалось и во многих работах, репрезентируюших семиотический подход к изучению эстетического знака. В статье рассматривается процессуальный характер современной живописи и указываются недостатки структурного анализа языка изобразительного искусства, настаивается на необходимости синтеза структурного анализа с анализом динамической сущности продуктов культуры (как это осушествлялось в лотмановской теории культуры).

\section{Esteetilise märgi abstraktne struktuur}

Saksa filosoof Walter Benjamin visandas mitmed hilisemad esteetilised teooriad. Rõhutades kunsti ekspressiivset olemust, defineeris Benjamin kunsti kui keele. Tema esteetikat iseloomustab kahe vastastikuse suuna interaktsioon: ühelt poolt ajalooliste protsesside mõistmisele tuginev kunstikriitika, teiselt poolt kunsti kriitilise kogemuse mõistmine ajalooprotsesside kujundajana. Selles osas on Benjamini esteetilise märgi ja Lotmani kunstiteose teooriates fundamentaalne sarnasus. Mõlemad teoreetikud määratlevad kunsti keelena ning selle struktuuri sünkroonilise ja diakroonilise esteetilise diskursuse lõikumisena. Artikkel vaatleb nüüdis- 
aegse maali funktsiooni muutumist representatsioonist autonoomse signifikatsioonini ehk sümboolsest väljenduse staatusest diskursuseks (grammatoloogilise écriture'i mõttes). Paralleelselt selle muutusega toimus nihe kunsti kultuurilises tähenduses. Kunsti kriitilise suhte maailma tagas mitte sarnasus, vaid väärtuste sõltumatus. Nüüdisaegne maal deklareeris kunstikeele valdkonnana, mis võimaldab üheltpoolt inimese kriitilist peegeldust ja teiseltpoolt ühiskonna representeerimist sel määral, kuivõrd kunst on neist tingimustest moraalselt sõltumatu. Kunsti autonoomse ja sotsiaalse olemuse dialektika on sügavalt mõjutanud maalikeelt, millele on viidanud ka mitmed semiootilised lähenemised esteetilisele märgile. Artikkel vaatleb kaasaegse maali protsessuaalset iseloomu ja näitab lühidalt maalikeele strukturaalanalüüsi puudusi, viidates strukturaalanalüüsi sünteesi vajalikkusele kultuuriproduktide dünaamilise olemusega (nagu näeme Lotmani kultuuriteoorias) 